SOUTHERN BRAZILIAN JOURNAL OF CHEMISTRY

SOUTH. BRAZ. J. CHEM., Vol. 5, No 5, 1997

\title{
SOLID SUBSTRATE FERMENTATION OF CACTUS PULP BY ASPERGILLUS NIGER
}

\author{
Arnaldo D. S. Júnior ; Rosangela B. Garcia; Dina G. Rodrigues and Jorge Nozaki* \\ (*) Departamento de Química, Universidade Estadual de Maringá \\ 87020-900 Maringá, Paraná, Brazil. Fax:044-263-5116 \\ E-mail: jnozaki@cybertelecom.com.br
}

\begin{abstract}
A new method of : culture is described to study the growth of Aspergillus niger on cactus pulp in the solid state. After extraction of viscous polyelectrolytes, employed in water treatment, the pulp of Cereus peruvianus was used as substrate for solid -state fermentation by a wild strain of A. niger. The good conditions for A. niger growth were $60 \%$ moisture, initial pH $3.0,35^{\circ} \mathrm{C}$, a nitrogen source made of $11 \%$ ammonium and $2 \%$ urea (on a nitrogen basis), $5 \%$ potassium phosphate, and $3.2 \mathrm{~g}$ spores $/ 100 \mathrm{~g}$ substrate. Related to the dry pulp, maximum fungal growth was observed after 120 hours of fermentation with $14 \%$ of protein production.
\end{abstract}

Keywords: solid-state fermentation, protein, Aspergillus, agricultural wastes, cactus

RESUMO. Investigou-se um novo método de cultura para o crescimento do Aspergillus niger sobre a polpa do cactus no estado sólido. Após a extração do polieletrólito natural, uma substância viscosa utilizada em tratamento de águas, a polpa do cactus Cereus peruvianus foi utilizada como substrato na fermentação sólida por cepas naturais de A.niger. As condições ótimas para o crescimento do A. niger foram: umidade de $60 \%, \mathrm{pH}$ inicial $3,0,35^{\circ} \mathrm{C}$, fontes de nitrogênio constituído de $11 \%$ de amônea e $2 \%$ de urea (baseados no nitrogênio), $5 \%$ de fosfato de potássio, e 3,2 $\mathrm{g}$ de esporos por $100 \mathrm{~g} /$ substrato. Em relação à polpa seca, o crescimento máxmo do fungo foi observado após 120 horas de fermentação com produção de $14 \%$ de proteína.

$\left.{ }^{*}\right)$ To whom correspondence should be addressed 


\section{INTRODUCTION}

Protein production by solid substrate fermentation ( SSF) using renewable sources received worldwide attention. This is an important way, in developed countries , of dietary changes for the partial substitution of animal protein with plant protein ${ }^{1}$.

Fermentation with Aspergillus niger,a filamentous fungi, have been studied for citric acid ${ }^{2}$,xylanolytic enzyme ${ }^{3}$, pectolytic enzyme ${ }^{4}, \beta$-glucosidase ${ }^{5}$, alpha and glucoamylase ${ }^{6}$, and nucleic acid-related substances production ${ }^{7}$. The study of fungal growth in SSF shows advantages over submerged cultures because liquid media are far from the natural environment of fung $i^{8}$.

Cereus peruvianus, a kind of cactus native in South America, is used as animal feed, despite its very low protein content, and is also used in the production of natural polyelectrolytes. The polyelectrolytes are used in water treatment as an auxiliary of flocculation and sedimentation ${ }^{9}$. Water, starch, cellulose, chlorophyll, and hemicellulose are the main constituents of cactus, with small amounts of pectin, and lignin ${ }^{10}$. After extraction of polyelectrolytes (soluble carbohydrates) there is the production of large amount of solid wastes constituted basically of fibers, starch, cellulose, and hemicellulose.It is the purpose of this research to use of cactus pulp, extraction of natural polyelectrolytes, as animal and human feed. Wild strains of $\mathbf{A}$. niger were used throughout this work, because of its high amylolytic and cellulolytic activities, for converting cactus pulp directly to feedable microbial protein by solid-state fermentation.

\section{EXPERIMENTAL PROCEDURE}

\section{Organism}

Wild strains of Aspergillus niger were isolated from decomposed wood pulps at different locations, and screened on agar plates containing $100 \mathrm{~g}$ of dried cactus pulp, $10 \mathrm{~g}$ $\left(\mathrm{NH}_{4}\right) \mathrm{SO}_{4}, 5 \mathrm{~g} \mathrm{~K}_{2} \mathrm{HPO}_{4}, 1.5 \mathrm{~g} \mathrm{MgSO}_{4} .7 \mathrm{H}_{2} \mathrm{O}$, pH 3.6, for 5 days. Cactus pulp was used as the only carbon source, and those black colonies that grew well under such environment, were isolated and retained for second screening. Those isolated organisms from the previous screening were cultured in flasks at $35^{\circ} \mathrm{C}$, after autoclaving $\left(110^{\circ} \mathrm{C}\right.$ for $20 \mathrm{~min}$.), at $\mathrm{pH} 3.0$, containing $10 \mathrm{~g}$ of $\mathrm{D}$-glucose and the same medium as the first screening . 


\section{Pulp preparation}

After removing the external chlorophyll, the cactus was cut in small pieces $(10 \mathrm{x}$ $30 \mathrm{~mm}$ ). Approximately $132 \mathrm{~g}$ of cactus pieces and $750 \mathrm{~mL}$ of tap water were transferred to 2 liters flask with shaking for $30 \mathrm{~min}$. The extraction of liquid and viscous natural polyelectrolytes ( soluble sugars ) was performed by maceration. The polyelectrolytes was kept at $4^{\circ} \mathrm{C}$ until use in water treatment. The solid waste was dried, exposing directly to the sun for 6 hours, before using as substrate for SSF.

\section{Solid-state fermentation}

Five gram of $\mathrm{KH}_{2} \mathrm{PO}_{4}$ (Merck-Germany), $\left(\mathrm{NH}_{4}\right)_{2} \mathrm{SO}_{4}$ (Merck) ( $11.5 \mathrm{~g}$ ), and urea $(33.7 \mathrm{~g})$ were added to $\mathrm{a}(30 \times 30 \mathrm{~cm})$ tray containing $100 \mathrm{~g}$ of dried cactus pulp. After adjusting the moisture to $60-65 \%$ with tap water and $\mathrm{pH} 3.0$ with diluted solution of sulfuric acid, $0.5 \mathrm{~g}$ of inoculum was transferred to its surface. Three more trays were prepared in the same way and put inside of the greenhouse at $35^{\circ} \mathrm{C}$. The first tray was on the botton surface, and the vertical distance among the first, second, third, and fourth trays were $15 \mathrm{~cm}$ respectively. The aeration was performed with an air compressor using silicone tube ( $60 \mathrm{~cm}$ lenght and $5 \mathrm{~mm}$ i.d) from the top of the greenhouse.

\section{Analytical methods}

\section{Protein and sugar determinations}

Fermented mold was soaked with $100 \mathrm{~mL}$ of phosphate buffer ( $\mathrm{pH} 6.9$ ) and stirred for $30 \mathrm{~min}$ at $60^{\circ} \mathrm{C}$. The extract was collected by filtration. The extraction process was repeated five times, all the extractants were transferred to flask, and the final volume was made up to $100 \mathrm{~mL}$ with distilled water. The method of Lowry et al was employed for protein determination ${ }^{11}$ using bovine serum albumin as standard. Reducing sugars was determined using dinitrosalicylic acid (DNS) $\operatorname{method}^{12}$, and starch was measured by polarimetric method.

\section{Sample preparation and starch determination by polarimetric method}

Crushed sample ( $2.5 \mathrm{~g}$ ) and $50 \mathrm{~mL}$ of $0.14 \mathrm{mol.L}^{-1} \mathrm{HCl}$ (Merck-Germany) were transferred to a $100 \mathrm{~mL}$ volumetric flask in a thermostatic bath with shaking for 15 minutes. After cooling, clarifier solutions constituted by $10 \mathrm{~mL}$ of 1 mol.L $\mathrm{L}^{-1}$ zinc acetate dihydrate (Aldrich-USA) and $10 \mathrm{~mL}$ of $0.25 \mathrm{mol. \textrm {L } ^ { - 1 }}$ potassium ferrocyanide trihydrate ( 
Aldrich ) were transferred to the flask, and the final volume was made up to $100 \mathrm{~mL}$ with distilled water. After one or two filtrations this solution was clear enough for polarimetric measurements. The sample solution was transferred to a $20 \mathrm{~cm}$ length polarimetric cell and the concentration was determined using the following relationship:

$$
\begin{aligned}
& {[\alpha]_{D(20)}=\frac{\text { observed rotation, degree } \times 100}{\text { optical path length }(\mathrm{dm}) \times \text { concentration }(\mathrm{g} / 100 \mathrm{~mL})}} \\
& \text { and } \mathrm{C}=100 \times \alpha / \mathrm{L} \times \alpha_{\mathrm{D} 20} \\
& \mathrm{D}=\text { line of sodium }(\lambda=589.3 \mathrm{~nm}), \mathrm{L}=\text { optical path length }(\mathrm{dm}) \\
& \mathrm{C}=\text { concentration }(\mathrm{g} / 100 \mathrm{~mL}), \alpha=\text { observed rotation }(\text { degree }) \\
& \text { The specific factor used for starch }[\alpha]_{\mathrm{D} 20} \text { was } 84.8\left(20^{\circ} \mathrm{C}\right) .
\end{aligned}
$$

\section{RESULTS AND DISCUSSION}

Table 1 shows the average composition of cactus Cereus peruvianus. The composition of cellulose, hemicellulose, chlorophyll, and lignin are variable and depends on cactus age, soil , time of collecting, etc. Table 2 shows the protein contents of cactus pulp, after extraction of natural polyelectrolytes, but before the solid-state fermentation.

Figure 1 shows the influence of moisture on mycelial growth and protein production by Aspergillus niger with optimal moisture observed at $60 \%$. Higher moisture may increase the viscosity, decreasing the porosity and oxygen diffusion. The $\mathrm{pH}$ also play an important role in solid fermentation. The average $\mathrm{pH}$ should be low enough, otherwise the system will have problems with bacterial contamination. Starting with $\mathrm{pH} 3.0$, after 140 hours of fermentation the $\mathrm{pH}$ increased to 6.0 ( Figure 4 ), even keeping the moisture approximately at $60 \%$. The increase of $\mathrm{pH}$ was due to the urea hydrolysis, and it should be controlled during the experiment. Starch consumption was not very related to the protein production, as shown in figure 2 , because the substrate used was constituted mainly by cellulose and hemicellulose. This was a clear indication that Aspergillus niger was able to produce not only amylolytic, but also hemicellulolytic and cellulolytic enzymes. On the other hand, the glucose consumption was closely related to the protein production as shown in Figure 3. 
SOUTH. BRAZ. J. CHEM., Vol. 5, Nº 5, 1997

A.D.S. Jüior, R.B. Garcia, D.G. Rodrigues \& J, Nozaki

Table 1. Average composition $\%(\mathrm{~m} / \mathrm{m})^{*}$ of cactus pulp ${ }^{10}$

\begin{tabular}{lc}
\hline Moisture & $75-80$ \\
Sugar & 12 \\
Pectin & 1 \\
Protein & $<1$ \\
\hline
\end{tabular}

$\left(^{*}\right)$ Cactus Cereus peruvianus

Table 2. Protein content $\%(\mathrm{~m} / \mathrm{m})$ in cactus pulp ( Cereus peruvianus )

\begin{tabular}{lc}
\hline Cactus pulp (powder) & $\%$ protein $(*)$ \\
\hline after extraction of chlorophyll $(* *)$ & 0.85 \\
without extraction of chlorophyll $(* *)$ & 1.58 \\
Protein determination by Lowry method & 0.80 \\
\hline & \\
\hline Average of six determinations. Standard deviation of $\pm 0,05 \%$. \\
method.
\end{tabular}


SOUTH. BRAZ. J. CHEM., Vol. 5, No 5, 1997

Figure 1. Influence of moisture on mycelial growth of Aspergillus niger

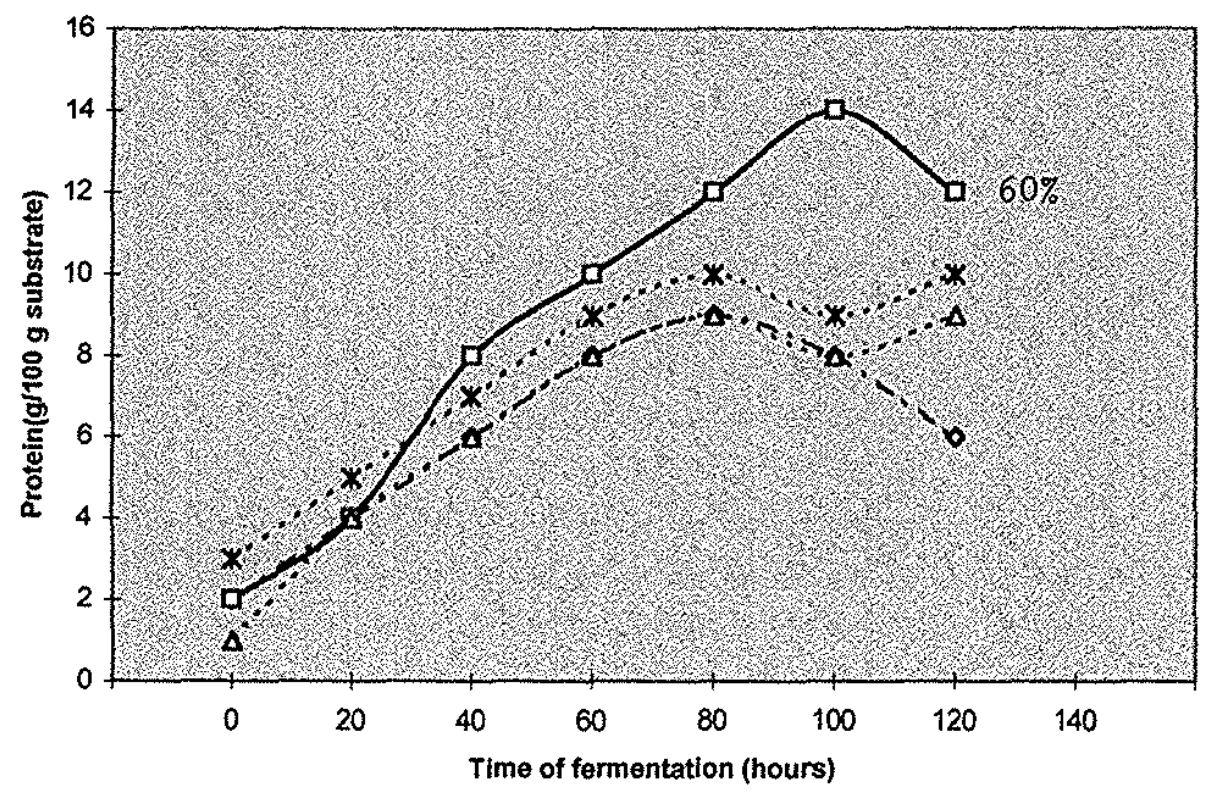

Figure 2. Starch consumption during fermentation

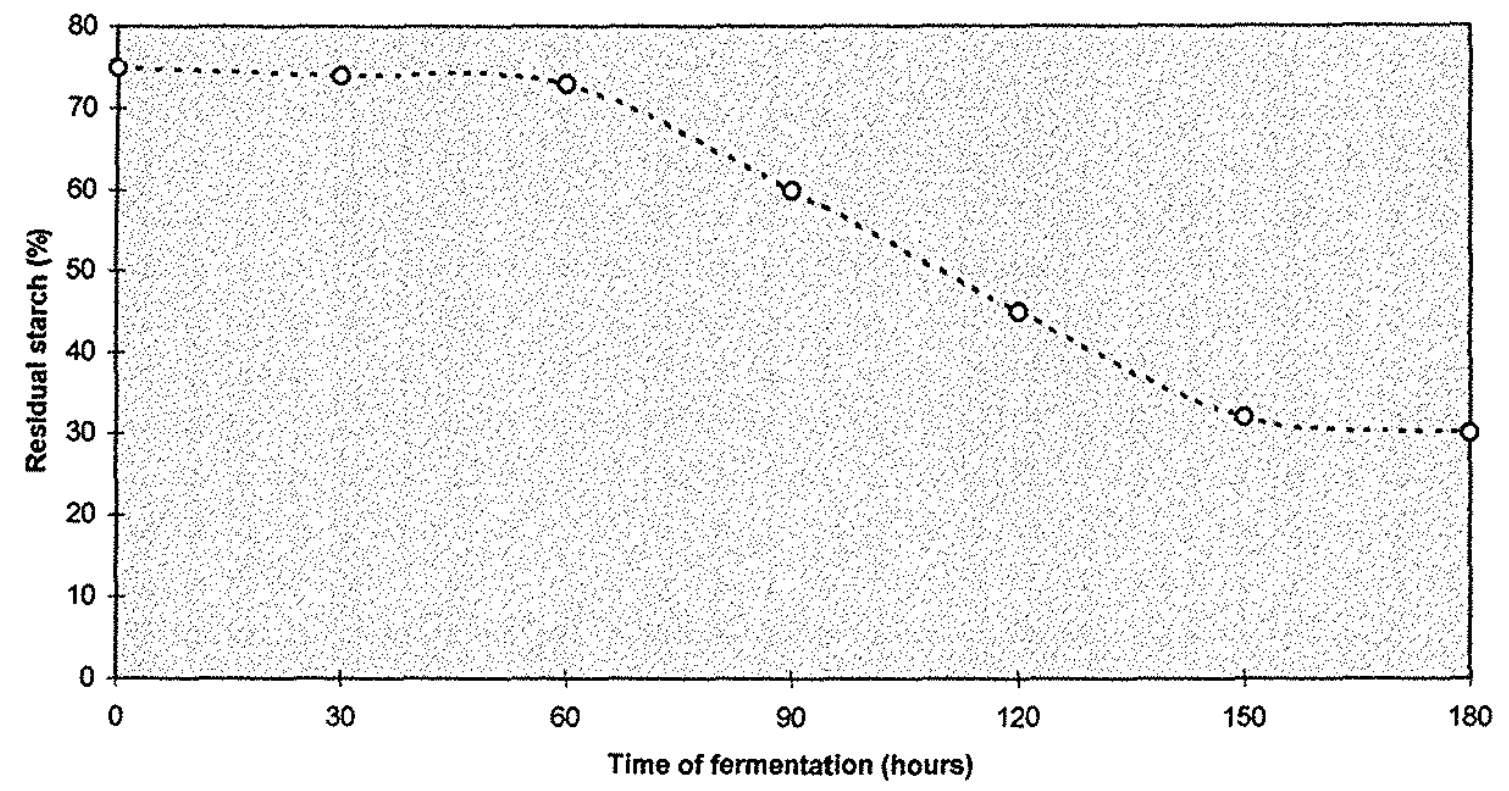




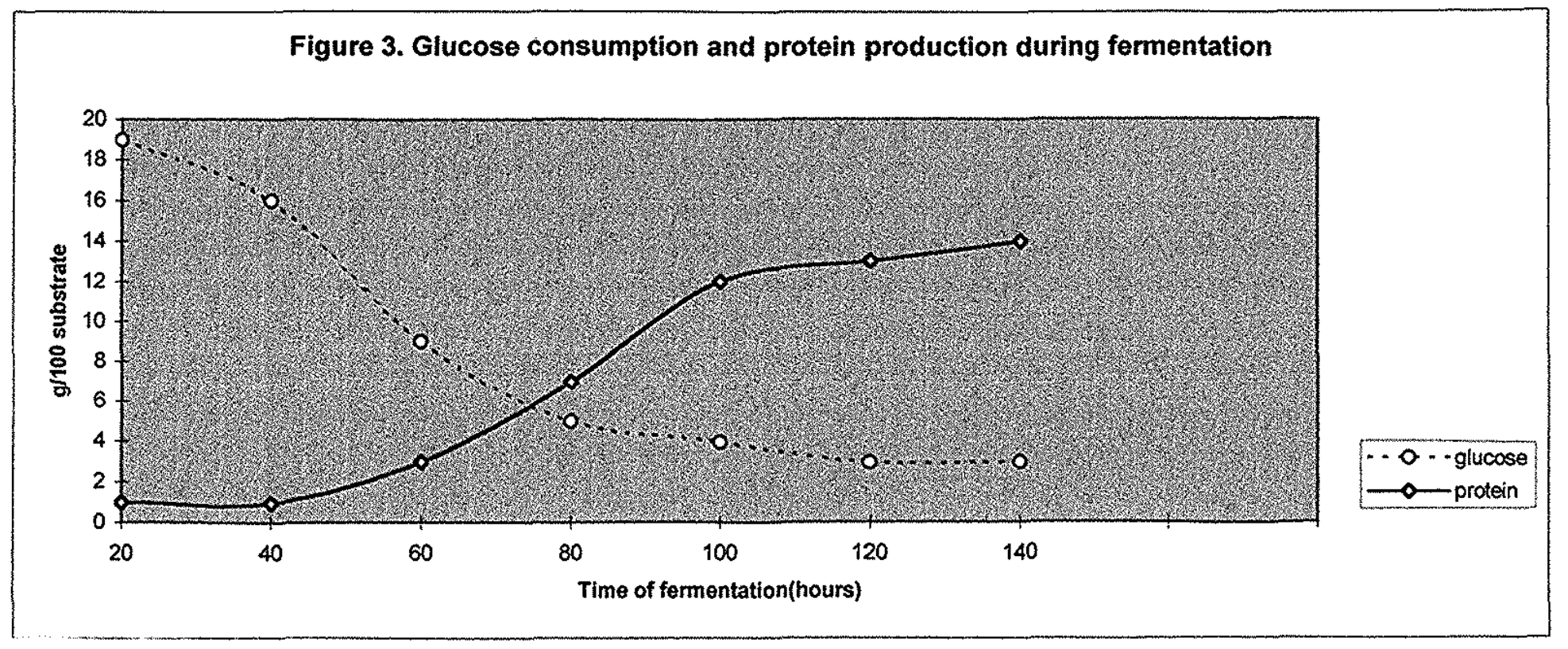

Figure 4. $\mathrm{pH}$ variation during fermentation

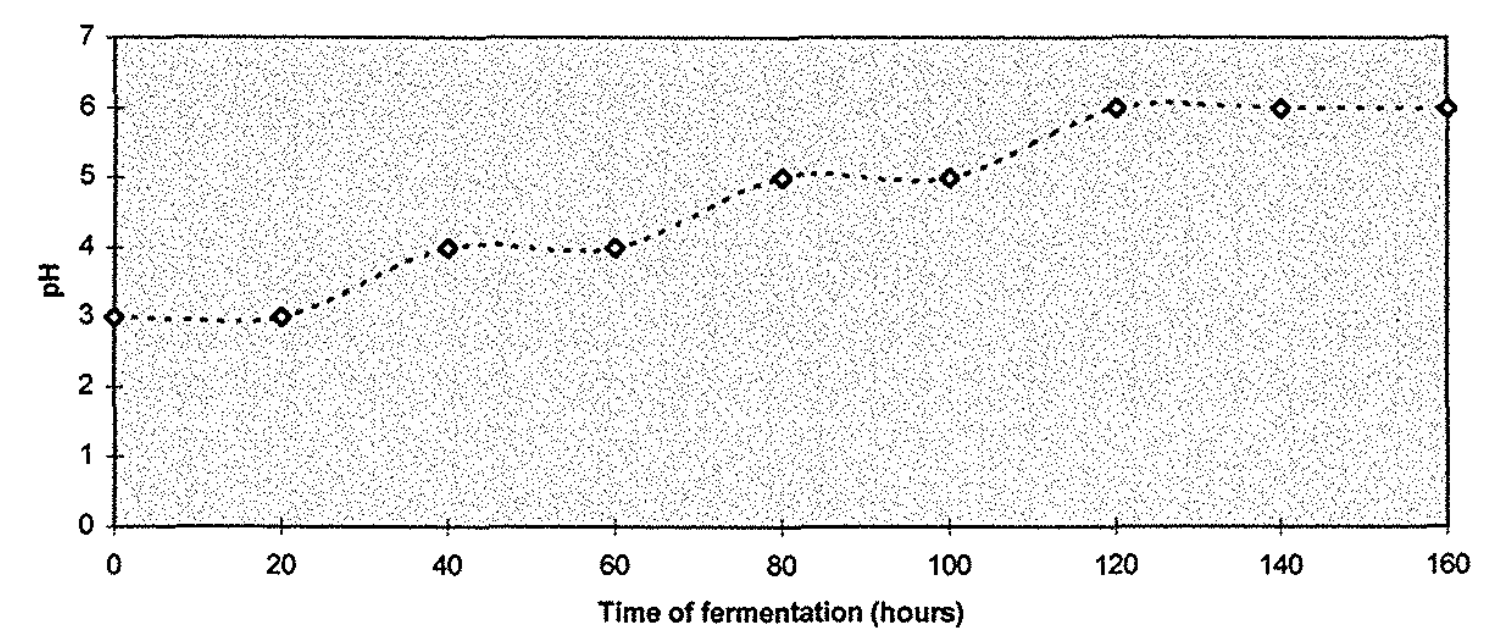


SOUTH. BRAZ. J. CHEM., Vol. 5, No 5, 1997

42

Cactus Pulp Fermentation by Aspergizlus Niger

\section{Conclusion}

High efficiency of protein production, reduced energy requirement, low wastewater output, nonaseptic conditions, and low capital investment were the advantages of SSF with wild strain of Aspergillus niger using cactus pulp as substrate. High viscosity, due to the presence of natural polyelectrolytes, was a drawback for oxygen diffusion. The difficulty of oxygen diffusion was the main limitation of the process .

\section{Acknowledgements}

The authors would like to thank FNMA/MMA, CAPES, and CNPq ( Brazil ) for financial support.

\section{REFERENCES}

1. Jwanny, E. W., Rashad, M.M., and Abdu, H.M., Applied Biochemistry and Biotechnology, 50, 71-78, (1995).

2.Mattey, M, Crit. Rev. Biotechnol. 12, 87-132,(1992).

3. Ferreira, M.C., Dias, A., Máximo, C., Morgado,M.J., Martins, G.S., and Duarte, J.C.

Applied Biochemistry and Biotechnology, 44, 231-242,(1994).

4. Antier, P., Minjares, A., Roussos, S., Raimbault, M., and Gonzalez, G.V, Enzyme

Microb. Technol., 15, 254-260,(1993).

5.Fadda, M.B., Curreli, N., Pompei, R., Rescigno, A., Rinaldi, A., and Sanjust, E, Applied Biochemistry and Biotechnology, 44, 263-270,(1994).

6.Cadmus, M. C., Jayko, L.G., Hensley, D. F., Gasdorf, H., and Smiley, K.L,Cereal Chemistry, 43, 658-669,(1966).

7. Carvalho, A., Faria, C.R., e Molinari, R, Eclética Quimica, 3, 55 67,(1978).

8. Raimbault, M., and Alazard, D, European J. Appl. Microbiol. Biotechnol., 9, 199-209,(1980).

9. Messerschimidt, I., Rodrigues, D. G., and Nozaki, J, Arquivos de Biologia e Tecnologia, 36 (4), 51-56,(1993).

10. La Mar, V. and Healy, K, Rev. Pure App.Chem.,13, 112-132,(1963).

11. Lowry, O. H., Rosebrough, N. J., Farr, A. L. and Randall, R. J, J. Biol. Chem., 193, 265-275,(1951).

12. Wood, T. M. and Bhat K. M, Methods in Enzymology, 160, 87-116,(1988). 